\title{
PRINCÍPIO DE PRAZER E EFEITO SUBJETIVO DA LEI MORAL EM KANT E FREUD ${ }^{1}$
}

\author{
Reginaldo Oliveira Silva ${ }^{2}$ \\ Universidade Estadual da Paraíba (UEPB) \\ https://orcid.org/0000-0003-1834-4541 \\ E-mail:rgnaldo@uol.com.br
}

\section{RESUMO:}

Após consolidar o fundamento objetivo da lei moral na razão pura prática, Immanuel Kant investiga o fundamento subjetivo e introduz o sentimento. De produto da razão, a lei moral será examinada como efeito sobre o ânimo, numa dialética de desprazer e prazer, da qual surge o sentimento moral. $\mathrm{O}$ presente artigo visa problematizar este aspecto da ética do filósofo à luz da Crítica da faculdade do juízo e dos conceitos princípio do prazer e princípio da realidade de Sigmund Freud. Ao colocar em questão a relação entre sentimento de prazer e moral nos dois pensadores, indaga se no filósofo não estaria em questão a descoberta da realidade interna da heteronomia.

PALAVRAS-CHAVE: Kant; Freud; Lei moral; Princípio do prazer; Sentimento moral.

\section{PLEASURE PRINCIPLE AND SUBJECTIVE EFFECT OF THE MORAL LAW IN KANT E FREUD}

\begin{abstract}
:
After seating the objective foundation of the moral law in the practical pure reason, Immanuel Kant investigates the subjective foundation and it introduces the feeling. Of product of the reason the moral law will be examined as effect on the vitality, in a dialectics of displeasing and pleasure, of which the moral feeling appears. The presente article seeks to problematize this aspecto f the ethics of the philosopher to the light of the Critic of judgement end of the relationship between beginning of the pleasure beginning of the reality in of Sigmund Freud. When putting in subject the relationship among pleasure feeling and moral in the thinkers, it is investigated in the philosopher would not be in subject the discovery of the interns of the moral law.
\end{abstract}

KEYWORDS: Kant; Freud; Moral law; Pleasure principle; Moral sentiment.

\footnotetext{
${ }^{1}$ Este artigo é resultado da participação no Programa de Iniciação Científica - PIBIC, financiado pela PróReitoria de Pós-Graduação e Pesquisa da Universidade Estadual da Paraíba-UEPB, Cota 2017-2018.

${ }^{2}$ Doutor em Letras e mestre em Filosofia. Professor Associado da Universidade Estadual da Paraíba (UEPB), Campina Grande - PB, Brasil.
}

SILVA, Reginaldo Oliveira. Princípio de prazer e efeito subjetivo da lei moral em Kant e Freud. Griot : Revista de Filosofia, Amargosa - BA, v.19, n.2, p.108-121, junho, 2019. 
Lugar comum na recepção da ética de Immanuel Kant, o formalismo não esgota as interpretações possíveis dos momentos inaugurais da ética moderna. Conceitos como vontade legisladora e reino dos fins, uma distinção mais precisa entre os imperativos hipotéticos e o categórico emergem na filosofia moral do filósofo, a fim de consolidar uma ética escrita na esteira da revolução copernicana. Também neste propósito fez-se a divisão da faculdade de apetição em inferior e superior, cada uma respondendo por graus distintos da determinação da vontade. A observar o método analítico que emprega para destrinchar os mecanismos da vontade, muito há a indagar sobre o percurso que, ao final, resulta no formalismo de que tanto é acusado e cuja menção, frequentemente, tende a desacreditar o valor das suas elaborações sobre a formação do sujeito ético.

É na fronteira entre a análise dos momentos constitutivos da (re)construção da lei moral e a sua fundamentação na razão pura prática, que temas como o sentimento e o prazer se introduzem e podem ser sugeridos como fio condutor de uma reflexão sobre a ética de Kant, sua importância e atualidade. Também aí reside a possibilidade de, pela via do princípio do prazer, em Sigmund Freud, trazer para a mesma as contribuições da psicanálise, sendo o contrário também possível. Se o sentimento de prazer constitui, também, um caminho de reflexão sobre a ética nos momentos decisivos da analítica da razão prática, compreender como Freud situa o princípio do prazer na trama psíquica permite ampliar a compreensão do que em Kant começa a se esboçar em torno do agir humano.

Ao situar o sentimento de prazer no cerne da arquitetônica da ética de Kant, quando o problema migra do fundamento objetivo para o fundamento subjetivo da lei moral, e considerando a primazia do princípio do prazer na vida psíquica, conforme pensou Freud, a reflexão aqui proposta parece de todo plausível. Uma empreitada a qual sugere, de início, o exame da analítica da razão pura prática, a fim de situar a lei moral tanto no aspecto objetivo, como doação da razão, no entender de Rogozinski (2008), quanto no subjetivo, como humilhação das inclinações; em seguida, analisar a função psíquica do princípio do prazer e as derivações que dele se seguem, numa dialética entre dor e supressão da dor, mas também naquilo que Freud irá nomear além do princípio do prazer, a pulsão de morte.

Tanto na Fundamentação da metafísica dos costumes quanto na Crítica da razão prática, a ética de Kant se "constrói", num primeiro plano, como virada radical da influência da norma sobre a vontade, da aposta na autonomia no campo da ação humana, consequentemente, do esforço de retirar da heteronomia a autoridade exclusiva sobre o sujeito. Num segundo plano, e por não ser suficiente apenas definir a lei nos seus termos abstratos, a empreitada se reveste da análise das determinações da vontade e os elementos que a constituem, sob a hipótese de que há uma superior um trabalho de "purificação" que resultará na lei moral e sua causalidade peculiar, a Liberdade.

Não somente os imperativos serão distinguidos segundo as suas finalidades, mas também serão banidas as forças que atuam, de fora, no indivíduo. As inclinações, a sensibilidade, os cálculos da prudência, todos relevantes para uma vontade empiricamente satisfeita, no dizer de Kant, patológica, serão postos de lado - embora não sejam demonizados -, na busca do fundamento da lei moral, cujo resultado revela, aos poucos, uma outra forma de determinação da vontade, por 
assim dizer, um deslocamento, que dos objetos empíricos ascendem para o indeterminado Sumo Bem, na Crítica da razão prática. É neste itinerário da analítica da razão prática que o prazer tem lugar e oferece outro caminho de interpretação, que permite, do exame da ética de Immanuel Kant, encontrar a psicanálise de Sigmund Freud. Não bastou ao filósofo determinar a forma da lei moral, encontrar para a vontade um lugar além das influências dos sentidos e do prazer proveniente do gozo dos objetos, era a ele necessário, a fim de defender o uso prático da razão pura, demonstrar o que se passa internamente como condição, no indivíduo, de reconhecimento do efeito da lei moral sobre a vontade.

$O$ sentimento de prazer pode ser situado na ética de Kant em três momentos, uma linha de continuidade que caminha da segunda para a terceira crítica. $O$ fundamento objetivo segue o percurso das formas de agenciamento da vontade, segundo esta se determina ou por meio de máximas ou de regras práticas, por fim, pelas denominadas leis prático-objetivas, de alcance universal. Ao já analisado na Fundamentação como imperativos, hipotéticos e categórico, acrescenta-se o aquém puramente subjetivo das máximas, por assim dizer, anteriores às legislações da razão prática. Seriam três as formas mediante as quais a vontade se determina, e na esteira destas formas todo o trabalho da analítica residirá em circunscrever os seus respectivos campos de legislação, a fim de estabelecer o terreno próprio da moralidade. Seja para gozar dos sentidos seja para alcançar a felicidade, a vontade se forma sob o domínio da heteronomia, o que a coloca de imediato sob o que Kant irá nomear, na Crítica da razão prática, princípio da felicidade ou do amor de si, contra o qual oporá, mais adiante, outro princípio, o da moralidade.

O movimento que opera essa divisão também se volta para o sentimento de prazer, pois, ao analisar a vontade segundo o critério da felicidade e dos objetos dos quais se busca gozar, emerge um sentimento. A investigação do fundamento da moral liga-se diretamente ao sentimento de prazer como efeito dos princípios materiais de determinação da vontade, consequentemente, a analítica da razão pura prática tem de necessariamente passar pelo gozo. Não bastando apenas pontuar a presença dos objetos, faz-se importante olhar para a satisfação, ou o agrado, que tais objetos proporcionam e para o efeito subsequente que deles se espera, não distinguindo o filósofo se a representação que produz o prazer origina-se ou nos sentidos ou no entendimento. $O$ que importa é se numa ou noutra é do prazer que se trata, se é o prazer que constitui um fim. Leia-se: "se a determinação da vontade depende do sentimento de agrado ou desagrado [...] então é indiferente através de que modo de representação é afetado" (KANT, 2016, p. 40).

O sentimento de prazer, como percepção interior ou, conforme se exprime em Antropologia de um ponto de vista pragmático, como "sentimento de promoção da vida" (KANT, 2006, p. 128), circunscreve-se ao restrito âmbito da faculdade de desejar inferior, de modo algum, nesses inícios, sendo aproximado da superior. O que sugere, consequentemente, que para onde Kant conduz a sua analítica não somente os objetos serão afastados, como também o será o prazer, mesmo que se possa alegar a existência de um prazer superior ao dos sentidos, como a busca de "satisfações e gozos mais finos" (KANT, 2016, p 40). No entender do filósofo, supor a existência de uma faculdade superior, implica em que a razão pura determine a vontade "sem 
pressuposição de nenhum sentimento, por conseguinte sem representações do agradável ou desagradável" (KANT, 2016, p. 41).

No momento em que a analítica desbrava os meandros da razão prática em geral, o prazer aparece como produto, ou finalidade, do princípio da felicidade, e somente será pensado na relação exterior com os objetos. Ele retorna, em seguida, quando, ao fundamento objetivo, Kant vê-se diante da necessidade de demonstrar como a lei moral atua ou o efeito que ela produz. Nas suas palavras, lê-se: "não temos que indicar a priori o fundamento a partir do qual a lei moral produz em si um motivo, mas na medida em que ela o é, o que ela efetiva (ou, para dizer melhor, tem de efetivar) no ânimo" (KANT, 2016, p. 117). Não mais interessa pensar o prazer porque associado aos propósitos nada nobres da vontade patológica, põe-se em questão, aqui, a relação da lei moral com o sentimento de prazer e desprazer (KANT, 2016, p. 117), em dois tempos, segundo os quais, o primeiro será negativo, porque promove dano às inclinações e ao amor de si, e o segundo, positivo, uma vez que produz o respeito pela lei moral (KANT, 2016, p. 120).

Kant pode, a partir daí, assegurar o alcance tanto objetivo quanto subjetivo da lei moral, e encerra-la num todo arquitetônico. Ao romper com o amor de si (KANT, 2016, p. 120), a ela garante objetividade; nessa ruptura, exerce sobre o homem uma humilhação, quando este compara a propensão sensível com a lei moral (KANT, 2016, p. 121). Assim formulada, a lei moral emerge subjetivamente de um primeiro sentimento, a dor da humilhação, sendo de início efeito negativo, o qual possibilita, em seguida, por conta do obstáculo afastado, o surgimento de um sentimento positivo, o sentimento moral (KANT, 2016, p. 122). O prazer que incialmente aparece na analítica apenas como impureza a ser banida das determinações da vontade, será mais uma vez erradicado, mas não como mais um elemento de análise, sobretudo como o que deve ser humilhado e constrangido, a fim de dar lugar ao respeito.

A considerar os dois tempos dessa dialética de desprazer e prazer, se o fundamento objetivo repousa na ideia da liberdade e na autonomia, o mesmo não se poderia dizer do subjetivo. Se nos inícios da analítica, a lei moral emerge como engenho da razão prática, o arremate que a consolida não parece de todo harmônico: a lei moral é produto da razão, mas também de uma violência que aquela exerce sobre as intenções de gozo empírico. A hipótese desta temporalidade, inscrita no fundamento subjetivo, permite pensar que o constrangimento do amor de si antecede o que vem a constituir o fundamento objetivo, e, por conseguinte, dá à lei moral a sua forma mais acabada, a ela atribuindo um lugar no interior do sujeito. Este caminho de análise se ampara, ainda, na Crítica da faculdade do juízo, onde Kant retomará essa mesma estrutura, fazendo da experiência do sublime, na dialética de desprazer e prazer, uma forma de (re)conhecimento da lei moral. No entanto, aqui, não é a lei moral, como efeito sobre o sujeito, que exerce pressão sobre as inclinações, e sim a própria razão, a fim de abrigar, e fazer-se reconhecida, no sujeito o seu produto mais refinado.

Embora com o objetivo de encontrar um acordo entre natureza e liberdade, a terceira crítica também visa promover, por meio deste acordo, "a receptividade do ânimo ao sentimento moral" (KANT, 2008, p. 41), conforme vem afirmado ao final da Introdução e melhor se revela na analítica do sublime. A dialética de desprazer e 
prazer segue a dinâmica esboçada na segunda crítica, da violência e humilhação da razão sobre o amor de si, desta vez, atacando as ambições da imaginação de ampliarse em face da grandeza na natureza. É o que se depreende dos dois tipos de sublime analisados por Kant, os quais mantém, segundo o constrangimento da sensibilidade e a faculdade a esta ligada, a imaginação, os mesmos momentos observados nos efeitos da lei sobre o ânimo.

Com o sublime matemático, a imaginação tenta se desembaraçar da grandeza da natureza por meio dos cálculos matemáticos do entendimento. Como a tarefa malogra, e daí decorre o desprazer, o ânimo não recua e, ao "ouvir a voz da razão" (KANT, 2008, p. 100), demonstra uma "faculdade do ânimo que excede todo padrão de medida" (KANT, 2008, p. 100). Surge aí a exigência de que exista no "ânimo humano uma faculdade que seja ela própria suprassensível" (KANT, 2008, p. 101), possibilidade de "ultrapassar todas as barreiras da sensibilidade" (KANT, 2008, p. 101). À descoberta da razão corresponde, ainda, o reconhecimento da destinação moral, desenvolvido com o sublime dinâmico. Enquanto o matemático desvenda para o conhecimento a faculdade superior da razão, o dinâmico desvela que a razão também possui um uso prático, e por aí Kant insere no acordo entre natureza e liberdade o sentimento moral.

No sublime dinâmico, a natureza é o que suscita medo, poder de destruição da vida, portanto, causa de desprazer ante a possibilidade do aniquilamento. Mas uma coisa é o temor que o objeto suscita, outra, o medo de si mesmo em face do objeto. Objetos que suscitam medo, como vulcões, o oceano revolto, "denominamos estes objetos sublimes", diz Kant (2008, p. 107), “porque eles elevam a fortaleza da alma acima de seu nível médio e permitem descobrir em nós uma faculdade de resistência de espécie totalmente diversa, a qual nos encoraja a medir-nos com a aparente onipotência da natureza". A natureza apresenta-se incomensurável e denuncia a insuficiência da imaginação ou do entendimento, mas oportuna encontrar "em nossa faculdade da razão um outro padrão de medida" (KANT, 2008, p. 107), e, neste, a lei moral. Se na segunda crítica a lei já se apresenta em seu aspecto sublime, agora aparece em sua dimensão subjetiva, não mais uma objetividade que apenas revela a perspectiva da aniquilação.

O sublime, continua o filósofo, "é uma violência que a razão exerce sobre a faculdade da imaginação somente para ampliá-la convenientemente para o seu domínio próprio, o prático, e proporcionar-lhe uma perspectiva para o infinito, que para ela é um abismo" (KANT, 2008, p. 111). Essa violência inicialmente imposta pela razão, à semelhança do que a lei moral exerce sobre as inclinações e o amor de si, como se viu a partir da segunda crítica, conduz à compreensão de que ao sublime está associado o sentimento moral, e permite sustentar que a lei moral tem origem, antes de tudo, no constrangimento e na humilhação, num desprazer que ou abate o ânimo do indivíduo ou para este aparece, de início, como ameaça à vida.

Do exame do sentimento de desprazer e prazer na ética de Kant, duas hipóteses podem ser elaboradas, das quais e com as quais se permite sugerir uma aproximação entre Kant e Freud, quanto ao lugar do sentimento de prazer na reflexão ética. A primeira diz respeito ao estatuto da autonomia, sobre o qual se organiza a ética de Kant - se era o intuito do filósofo fundar uma ética além da heteronomia, considerar o desprazer como primeiro efeito da lei moral para, só depois, fazer surgir o sujeito 
moral, ao que parece, ele estaria muito mais elaborando a internalização da heteronomia, a esta conferindo sobrevida no ânimo do sujeito. A segunda, ligada à primeira, residiria em que ao ter em conta o efeito negativo primário da produção de desprazer, a lei moral se constitui como lei interna, num processo que se repete cada vez que ao indivíduo se apresenta o gozo da felicidade.

A primeira dessas consequências permite aproximar da lei moral o Supereu freudiano, interpretação comum, por vezes balizada pelo próprio Freud nos textos nos quais ele busca refletir sobre a ética. A moralidade seria um sintoma (GOLDENBERG, 1994, p. 15), pulsão deslocada, a qual resulta da recusa de fruição da Trieb (GOLDENBERG, 1994, p. 35), um fetiche (EAGLETON, 1993, p. 65). Antes de ser um engenho da razão, a consciência moral possui uma natureza psicológica (GOLDENBERG, 1994, p. 15), o que melhor explica a análise que Kant faz sobre o fundamento subjetivo da lei moral, para o qual, como se viu, constrangimento e humilhação atuam sobre o indivíduo ainda sob os estímulos patológicos da vontade. A lei moral, e a consciência que ela engendra quanto à violência da razão sobre o homem empírico, possuiria, portanto, uma realidade psíquica, seria ela um sintoma da frustração da vontade patológica. A considerar o propósito de Freud de investigar a necessidade psicológica dos sentimentos morais (GOLDENBERG, 1994, p. 15), a hipótese que aí se levanta também se inscreveria na letra do texto kantiano.

A busca por uma ética da autonomia, que a princípio se fez com a negação das forças exteriores, heterônomas, que sobre o indivíduo exercem influência, desemboca na forma da sua interiorização. Este aspecto muito contribui para compreender as relações entre a lei moral kantiana e o sujeito freudiano, do ponto de vista do Supereu. Como em Freud o Supereu surge depois dos primeiros enfrentamentos com a necessidade, não seria de todo implausível considerar que também a lei moral emergiria do confronto com a vontade patológica. $O$ imperativo categórico, como produto da razão, obedeceria à mesma lógica e temporalidade que vai resultar na formação da instância crítica interna, segundo o pai da psicanálise. Ao descobrir como a lei moral atua internamente, Kant parece muito mais instaura-la no mais íntimo do sujeito, o que sugere, por um lado, que ele descobre o topos interno da heteronomia - mesmo que o propósito resida em fundar uma ética da autonomia -, tornando-se consciência; em segundo, a maneira como o filósofo pensa a lei moral, em seu aspecto subjetivo, aproxima-se do que em Freud vem a constituir o processo secundário, em que o sujeito, formado na e pela renúncia, a posteriori, reproduz sobre si mesmo a recusa de satisfação, uma vez que a instância crítica nele já está instaurada.

Ao tomar o princípio do prazer como fio condutor de uma análise da ética kantiana, quanto aos dois tempos da instauração da consciência moral, a saber, o desprazer da humilhação e o prazer do reconhecimento da lei moral, é possível reler a ética de Kant tanto quanto ao processo primário como em relação ao secundário. Assim, Kant e Freud, em que pese a diferença aproximada de um século, trabalham sobre o mesmo aspecto dos sentimentos morais, sobre a emergência de uma nova relação com a lei. Embora seja possível pensar a lei moral como Supereu, isto se restringe a pensa-la apenas no momento em que está constituída como consciência interna da lei. A considerar que, antes, há o momento em que, segundo se lê na 
terceira crítica, a razão exerce pressão sobre o sujeito empírico, sendo por conseguinte causa de desprazer, a lei moral pode ser examinada segundo a primazia do princípio do prazer nos processos psíquicos.

A começar por $O$ eu e o id, neste escrito de 1923 o princípio do prazer se situa ao lado dos primeiros investimentos objetais, que serão afastados no propósito de apaziguar um desprazer possível, e o princípio de realidade surge como barganha do Eu com o mundo exterior. A partir da percepção sensorial, o aparelho psíquico investe em acomodar os estímulos, afastando aqueles que podem resultar em desprazer. Mas como o Eu não é apenas uma superfície corporal, a instância psíquica aí se institui (FREUD, 2011, p. 34): o processo inicial que estabelece para o aparelho psíquico a divisão em três instâncias ou sistemas, o Inconsciente, o Pré-Consciente e o Consciente, que atuam e filtram o que do exterior e do interior é percebido. Como o que está em jogo é a aceitação ou não das excitações, outra subdivisão se estrutura: o Eu e o Supereu ou Ideal do Eu. Isto se dá porque as renúncias objetais não significam o abandono do objeto, ao contrário, diz Freud (2011, p. 35), "um objeto perdido é novamente estabelecido no $\mathrm{Eu}$, ou seja, um investimento objetal é substituído por uma identificação".

A renúncia primeira não elimina o objeto, antes, porque constituidora do $I d$, promove uma representação interna que mantem a reivindicação de satisfação. $O$ objeto "migra" do exterior para o interior, e será representado pelo $I d$, e neste migrar, engendra o Supereu, cuja dupla função reside em perpetuar o processo de repressão, mas também de defender os interesses de satisfação do Id. Vê-se, portanto, que o Eu se forma neste duplo movimento, em que o primeiro diz respeito à renúncia objetal, que funda as instâncias psíquicas conforme acomodam a percepção; o segundo, com a identificação do objeto renunciado, constituindo um representante interno, a instância crítica ou consciência moral.

Nesse segundo momento, repousa a origem do Supereu, embora para efeito de análise não se possa afastar o primeiro, importante, aqui, para fazer a leitura da lei moral, considerando os dois tempos nos quais Kant a constitui: da humilhação dos sentidos, da qual se segue o reconhecimento da lei moral. Nesta linha, a lei moral corresponde à estrutura do Supereu, porém, como para este se constituir como instância psíquica tem de ocorrer a identificação com o objeto de início renunciado na lida com a percepção exterior, valeria também para a ética de Kant a mesma estratégia de constituição da instância crítica. É o que se depreende dos dois momentos que Freud desenvolve para a análise da formação do Supereu. Primeiro, o narcisismo, o qual será (para ficar apenas em $O$ eu e o $I d$, já que, como ele indica em nota, também o desenvolve em Introdução ao narcisismo e Psicologia das massas e análise do $\mathrm{Eu}$ ) uma identificação com traços do objeto, oferecendo-se "ele próprio ao Id como objeto de amor, procura compensá-lo de sua perda" (FREUD, 2011, p. 37). $O$ segundo momento, sob a suspeita de que essa identificação ocorre em idades mais tenras, remete ao complexo de Édipo, nos enfrentamentos da criança com os primeiros objetos de amor, a mãe e o pai, e o conflito que daí se segue, até a conformação de si.

Em que pese a trama dessas relações primordiais da infância, o que importa aqui é isolar os dois tempos da constituição do Eu, da relação com os objetos e a consequente renúncia destes para a formação da instância crítica. No abandono da 
mãe ou do pai como objeto de amor, a menina e o menino desenvolvem a identificação com um ou com outro, conforme o caso, a fim de fazer devir o feminino ou o masculino. Aqui residiria a saída do complexo de Édipo, no entender de Freud, uma alteração no Eu que nada mais é que a formação do Ideal do eu ou do Supereu. É este o sentido da afirmação que conclui as análises do psicanalista nessa seção de $O$ eи e o id, de que o Supereu, porque teria origem nas primeiras escolhas objetais, as quais tiveram de ser reprimidas, mas também em virtude das identificações subsequentes. O ideal do Eu constitui o Eu masculino e o feminino, mas também acumula as funções de advertência e proibição (FREUD, 2011, p. 42-43), e nisto atua como imperativo categórico, representa o que há de ideal mais elevado, e porque é o representante da relação com os pais, vem a ser o herdeiro do complexo de Édipo.

A considerar que o Supereu, como instância acusatória, reencena, para o e no indivíduo doravante constituído em Eu, um conflito real que teve de ser suprimido, e o faz como consciência moral, possuiria ele uma incidência secundária - nos termos de Freud, do processo secundário. Neste sentido, a hipótese de que a lei moral corresponde ao Supereu - ou, o que daria no mesmo, que este é o "representante psíquico" da lei moral - permite sustentar que a lei moral é herdeira da humilhação dos sentidos, sendo ela um engenho da razão num duplo sentido: primeiro, como capaz de, de si mesma, exercer influência sobre a vontade; segundo, porque, ao humilhar os sentidos, compensa o seu gesto com a doação da lei moral. É o que se pretendeu destacar tanto no fundamento subjetivo, na Crítica da razão prática, quanto na analítica do sublime, nos quais se observou que, ao passo que a lei moral humilha a presunção, em seguida, ela produz como resultado o sentimento moral. $\mathrm{Na}$ mesma linha, no momento em que a razão humilha a imaginação, a esta apresentando os limites da sensibilidade, em seguida, faz-se reconhecer como faculdade superior, mas também como força doadora de lei a ser investida pelo sujeito em face das ameaças da natureza.

O que ocorre na Crítica da razão prática seria correspondente ao processo secundário, quando a proibição do objeto não mais vem de fora, sobretudo, faz morada no íntimo do sujeito então constituído. Por sua vez, a analítica do sublime remete o constrangimento para mais aquém, ataca a presunção e a busca de gozo da imaginação ou da sensibilidade, e o sentimento moral surge como consequência. Lá, a lei moral já constituída humilha o sujeito em suas pretensões de satisfação sensorial; cá, é a razão que promove o desapego, e como consequência a lei moral se apresenta. Como condição da consciência moral, a humilhação dos sentidos teria dois significados, a depender de onde se parta, se da segunda crítica, se da analítica do sublime, na terceira crítica. A analítica do sublime corresponderia à primeira renúncia das escolhas objetais, enquanto a segunda crítica à repetição da proibição própria do Supereu. Ou seja, parece válido dizer que o que a segunda crítica afirma do fundamento subjetivo já seria um efeito do trabalho da razão, tal como se deslinda na terceira crítica - primeiro a razão humilha os sentidos, derivando daí a lei moral; esta passa a reproduzir no sujeito aquilo que a razão, antes, promoveu.

Por outro lado, e na esteira do que acima se analisou, os dois momentos da análise da lei moral, seja pela via da analítica da razão prática seja pela do sublime, trazem como traço em comum o sentimento de prazer. Ao toma-lo como fio condutor 
de uma reflexão da ética de Kant pareceu plausível examinar a lei moral como resultado da censura que a razão exerce sobre os sentidos ou sobre o homem empírico, primeiro promovendo desprazer e, em seguida, dando-se o prazer de um reconhecimento do homem a um destino mais elevado. Por essa via, viu-se como possível aproximar a lei moral kantiana do Supereu em Freud. Assim como o Supereu surge do abandono dos primeiros investimentos objetais, também ele tem origem na identificação com os objetos, pense-se pela via do narcisismo ou pela do complexo de Édipo - o que há aí de comum é que o objeto investido será incorporado pelo Eu no trajeto da sua formação.

A preservação do objeto investido no interior do sujeito indica que o momento inicial da formação do Eu repete-se na realidade psíquica, onde o sujeito reproduz a cena primária da renúncia. E aqui surge a pergunta, mais acima formulada como segunda consequência da análise da ética kantiana por meio do sentimento de prazer, sobre se a lei moral não herdaria, também, esse quadro de repetição característico do segundo momento em que o Eu freudiano refaz a primeira cena, desta vez, acionando um agente da proibição ou da repressão, o Supereu, ele mesmo inerente ao sujeito. Para tal, o propósito de examinar a ética de Kant a partir de Freud, ou de, da leitura do Freud, empreender uma releitura da ética de Kant, teria de confrontar a descoberta freudiana da compulsão à repetição, e de que maneira a compulsão que está associada ao princípio do prazer pode também trazer novas luzes para um exame das consequências da ética kantiana. Se assim for possível, a humilhação das inclinações, como primeiro momento da tomada de consciência da lei moral, se repetiria no sujeito moral a cada confronto entre vontade patológica e vontade orientada pela razão, com prejuízos para aquela.

Em "Formulações sobre os dois princípios do funcionamento psíquico", ensaio de 1911, o princípio do prazer se define, de início, como tendência ligada aos processos primários inconscientes, e como a Freud interessa a "significação psicológica do mundo externo real" (FREUD, 2010, p. 110), a ele opõe o princípio da realidade. Porque o princípio do prazer visa, de início, equilibrar o aparelho psíquico quando este é perturbado por estímulos internos, das duas saídas possíveis para o apaziguamento psíquico, ou a alucinação por meio dos sonhos ou a consideração das "circunstâncias do mundo exterior", o artigo investe nesta última, a fim de desenvolver as transformações que decorrem, para o indivíduo, quando o mundo real se torna balizador da frustração que o princípio do prazer tenta devolver ao estado anímico anterior à perturbação.

O princípio do prazer consiste na busca do prazer mas também em evitar o desprazer, dele se originando o princípio da realidade, que, em vez de substitui-lo, prolonga-o, a ele acrescentando a relação de objeto e a atividade da memória e do pensamento. Ele será acionado sempre que ao indivíduo se apresentar algum sinal de perigo ou sinal de desprazer, conforme se exprime Freud em Inibição, sintoma e angústia, de 1926, tenha origem interna ou externa. Dois destinos são aí possíveis, a saber, ou alucinar no sonho a satisfação frustrada ou negociar com a realidade. A diferença, portanto, entre o ensaio de 1911 е $\mathrm{O}$ еи е o id, de 1923, é que no primeiro será pinçado o princípio da realidade e como o mesmo modifica o programa da busca do prazer, e nesse último a perspectiva se expande, pois trata-se de investigar a 
formação do Eu nas relações com o mundo exterior mas também com as reivindicações do interior representadas pelo $I d$.

Essa perspectiva de uma dupla origem do sinal de desprazer melhor se inscreve em Inibição, sintoma e angústia, inclusive porque explora mais as derivações do princípio do prazer. Não se põe aí em questão as formas de tornar conscientes as percepções externas ou internas, sobretudo busca traçar os enfrentamentos do Eu com o Supereu e o Id. O sinal de desprazer interior se assemelha ao sinal de perigo exterior, contra os quais deve investir o Eu para evitar o desprazer. Contra o perigo externo, empreende-se uma tentativa de fuga, a fim de "retirar o investimento da percepção do que é perigoso" (FREUD, 2014, p. 21); no entanto, quando o perigo é interior, a repressão exerce a mesma função, desta vez, contra os investimentos do Id.

Embora as intenções dos textos de 1923 e 1926 se distingam, já que Freud num investiga a formação do Eu, e neste, como nesta formação o Eu faz frente ao Supereu e ao Id, produzindo sintomas e angústias como formas de defesa, o princípio do prazer, porque mais primordial, tem a sua estrutura revelada. Uma carga de energia, vinda de fora ou de dentro do indivíduo, se aparenta ser causa de desprazer, deve ser de imediato afastada, ou por meio da repressão ou pelo exame das circunstâncias do mundo exterior. Neles, e no ensaio de 1911, vê-se que o princípio do prazer atua em dois tempos: o das excitações, venham elas do exterior ou do interior, e o das soluções para a frustração das satisfações, quando ou o sinal de perigo ou desprazer é acionado. Nestas, dá-se o investimento ou na fuga ou na repressão, mas também na introdução do princípio de realidade.

O exame da ética do Kant sob o fio condutor do sentimento de desprazer e prazer permitiu pensar a lei moral como tendo origem num efeito primário sobre as inclinações, tanto no seu fundamento subjetivo, na segunda crítica, quanto na analítica do sublime, na terceira crítica. A trilha que aí se seguiu possibilitou colocar a questão sobre a origem apenas formalista da lei moral, a ela atribuindo a anterioridade do desprazer como condição do reconhecimento da lei. Sobre as dores do homem empírico, o sujeito racional e, por conseguinte, o sujeito moral viriam a se consolidar perante as vicissitudes da sensibilidade. Esta mesma dialética sedimenta o funcionamento do princípio do prazer conforme pensado por Freud: das excitações externas ou internas, ele será acionado no propósito de conter a ameaça do desprazer, em seguida, gerando satisfações substitutas, entre as quais se inscreve a regulação do prazer pelo princípio da realidade, que bem pode assumir a forma do imperativo categórico.

Se o desprazer, do qual deve prevenir-se o sujeito ao acionar o princípio do prazer, tem origem, de início, na percepção externa, mas, em seguida, nos investimentos do Id, por conta da incorporação dos objetos renunciados, e nas acusações culpabilizadoras do Supereu, a lei moral ocuparia lugar neste segundo tempo da correção do princípio do prazer ou em repressão ou no princípio da realidade. E neste ponto se justifica a relação entre a lei moral kantiana e o Supereu freudiano, e parece plausível a hipótese de que a lei moral, apesar de, quanto ao seu fundamento objetivo, fazer frente à heteronomia, não importa se dos objetos da sensação se das éticas cosmológica e teológica, não seria muito mais uma interiorização das determinações exteriores da vontade. Por outro lado, se a 
conclusão acima se baseia na Crítica da razão prática, como se viu, na analítica do sublime, o constrangimento se exerce não pela lei moral e sim pela razão, o que a lei moral faz é repetir o que a razão anteriormente leva a cabo na frustração das satisfações da vontade patológica.

Seguindo essa mesma chave de interpretação, da leitura da ética de Kant a partir da psicanálise freudiana, com a qual aqui se investe na compreensão de uma origem menos formal da lei moral, outro aspecto do princípio do prazer se insere na reflexão. Em sendo possível sustentar que a humilhação da presunção pela lei moral é uma repetição de um ato anterior da razão sobre a sensibilidade, Além do princípio do prazer, escrito por Freud em 1920, lança a problematização noutro âmbito. Neste texto, escrito por Freud em 1920, ao princípio do prazer são associadas as noções de compulsão à repetição e pulsão de morte. Se resta plausível o que até aqui se disse, a fim de melhor pensar a lei moral ali onde Kant a constitui em relação ao sentimento de desprazer e prazer, quando entra em jogo a repetição, e, em sendo, se seria possível que o que torna a lei moral reconhecível pelo sujeito estaria também submetida à repetição.

Após retomar a definição do princípio do prazer, afirmando a sua primazia no funcionamento psíquico, Freud a ele acrescenta o princípio de constância, a tendência à estabilidade, quando o aparelho psíquico sofre alguma perturbação referente à quantidade de excitação na vida psíquica. Retoma, ainda, os dois tempos que acima se discutiu, desta vez, nomeando-os como inibições do princípio do prazer, "as dificuldades do mundo externo" (FREUD, 2010a, p. 165), que em virtude da autoconservação do Eu impele à sua modificação em princípio de realidade, e os "conflitos e cisões dentro do aparelho psíquico" (FREUD, 2010a, p. 166), para os quais a repressão se apresenta como saída para o desconforto. Mas também deve-se acentuar que o investimento em afastar a fonte de desprazer será sempre acionada a cada ocasião de ruptura.

Em termos esquemáticos, o princípio do prazer, como processo primário, será mobilizado toda vez que o mundo exterior e o mundo interior - antes, a percepção externa e a interna - apresentam-se como perturbação da paz psíquica, fazendo derivar ou o princípio da realidade ou a repressão. Até aqui, nada de novo, salvo a introdução da constância como finalidade do princípio do prazer, o que a este confere novo propósito, além da obtenção de satisfações instintivas, a saber, a ele também é atribuído o esforço de retomar, por assim dizer, a ausência de perturbação da alma. E eis em que assenta a hipótese de Freud quanto à existência do mais além do princípio do prazer: porque os instintos reprimidos com o fim de evitar o desprazer continuam a reivindicar satisfação, as investidas do princípio do prazer tendem à repetição, e a repressão se faz novamente necessária. Desta maneira, residiria no princípio do prazer, a ele imanente, uma compulsão à repetição, de cuja investigação se ocupa a continuidade do texto de Freud.

Que o princípio do prazer abrigue em si mesmo a repetição, isto fica claro logo nas primeiras páginas do texto de Freud, em virtude da tendência ao repouso. No entanto, como junto àquela se coloca a suspeita de uma atividade psíquica anterior ao princípio do prazer, não apenas tem o autor de fundamentar a repetição como também nomear essa atividade. É o que ele passa a discorrer a seguir, com a neurose traumática, o fort-da e, por meio da revisão da teoria dos instintos, cogita a 
existência do instinto primordial, o retorno ao inanimado, bem como os tateios pela biologia e a filosofia.

Sobre a neurose traumática, de começo, apenas pontua que nos sonhos desses neuróticos o retorno a fases saudáveis seria indício da repetição, e deixa para mais tarde o desenvolvimento. O fort-da parece conter uma estrutura mais acabada para o propósito, o qual consiste em jogar para longe de si um carretel de linha, logo em seguida fazendo-o reaparecer, gesto que oscila entre desprazer e prazer. Criado pelo infante, o jogo pretende encenar o desaparecimento, fooooooooort ("foi embora"), e o reaparecimento, daaaaaa ("está aqui"), da mãe. Duas interpretações são projetadas para os dois tempos do jogo, com as quais dá-se o registro não apenas da compulsão à repetição. A primeira registra o efeito da conquista da cultura e da renúncia instintual, a saber, o empoderamento da criança, pois marca a saída da passividade para a atividade, ao apropriar-se, por meio do jogo, da cena traumática causa de desprazer.

Na segunda interpretação, Freud se pergunta pela maior intensidade do primeiro ato em relação ao segundo, e conclui que assim é em virtude da satisfação de um impulso, o desejo de vingar-se da mãe. O jogo infantil corresponde ao princípio do prazer e a repetição a este inerente, enquanto a atenção ao primeiro ato remete ao além do princípio do prazer, à busca de satisfação de um desejo anterior. Com isto reitera-se a hipótese do texto, no dizer de Freud (2010, p. 174): "se a tendência a elaborar psiquicamente algo impressionante e dele apropriar-se inteiramente pode se manifestar de modo primário e independente do princípio do prazer". Dois sentidos para o jogo, dois tipos de prazer: o prazer do jogo, passagem da passividade para a atividade, e o prazer de vingar-se, no jogo, do responsável pela experiência desagradável (FREUD, 2010, p. 176). Esta última confirma a suspeita de Freud, da existência de uma tendência mais "primitiva do que o princípio do prazer" (FREUD, 2010, p. 176).

Se até então, Freud está às voltas com a defesa do mais além do princípio do prazer, avança ele quando retoma a relação dos sistemas $C s, P$-cs e Ics, quanto às excitações provenientes das percepções externas e as internas, de prazer e desprazer, e a introdução do instinto primordial do retorno ao inanimado. Porque mais superficial, a consciência se encarrega de filtrar as percepções, é um dispositivo para a recepção a estímulos e proteção contra os excessos, mas também recebe-os vindos do interior - com as exteriores, ela dialoga com o P-Cs, quanto às outras, com o Ics, como já se viu em $O$ eи e o id, acomodando-as conforme a intensidade das sensações. No entanto, e eis o ponto em que Freud encontra o mais além do princípio do prazer, há percepções as quais são tão fortes que rompem a proteção, tornando-as impossíveis. Consequentemente, acarretam num investimento psíquico antes que o princípio do prazer seja acionado, no propósito de evitar o desprazer e manter atuante a busca do prazer.

Sobre essas percepções serve de exemplo a neurose traumática - aqui, ele melhor explica o que nos inícios apenas pontuou -. Elas rompem com o fluxo entre os sistemas psíquicos, exigem a "paralisação ou redução do funcionamento psíquico restante" (FREUD, 2010, p. 193), de modo a resolver a ruptura. Sugerem, portanto, que em vez de investir no programa do prazer, tem o aparelho psíquico de ligar tal percepção ao psíquico, o que novamente corrobora com a hipótese de Freud, no seu 
dizer: a de "vislumbrar uma função do aparelho psíquico que, sem contrariar o princípio do prazer, é independente dele e parece mais primitiva que a intenção de obter prazer e evitar o desprazer" (FREUD, 2010, p. 196). Antes do trabalho do princípio do prazer, há a exigência de ligar ou desligar as percepções do aparelho psíquico. E esta anterioridade também está relacionada às percepções internas, cujos estímulos derivam dos instintos, "os representantes de todas as forças procedentes do interior do corpo e transmitidas ao aparelho psíquico" (FREUD, 2010, p. 198).

Na linha da repetição do princípio do prazer, pode-se dizer que corresponde aos dois tempos com os quais se examinou a influência da razão sobre a presunção, na segunda crítica, e da imaginação, na terceira crítica. $O$ desprazer causa de sofrimento e dor, não importa se está em jogo a presunção ou as ambições da imaginação, é uma ameaça à vida e, consequentemente, à busca de satisfação. A lei moral apareceria, portanto, como princípio de realidade cujo objetivo seria apaziguar o ânimo. É o que ocorre com o reconhecimento subsequente da lei moral, que atuaria no sentido de trazer ao sujeito a paz anterior ao estímulo que engendra a vontade. Responderia ela à necessidade mais primordial de retorno ao inanimado, à ausência de perturbação. Em sendo assim, sustentar que a lei moral kantiana pode ser pensada segundo a trama psíquica que engendra o Supereu e à repetição da cena de constrangimento, parece ser sustentável, o que confere ao engenho kantiano a radicalidade revolucionária que motiva a construção da sua ética. 


\section{Referências:}

EAGLETON, Terry. "O imaginário kantiano", In.: A ideologia da estética.

Tradução Mauro Sá Rego Costa. Rio de Janeiro: Zahar, 1993.

FREUD, Sigmund. Além do princípio do prazer. Tradução Paulo César de Souza. São Paulo: Companhia das Letras, 2010a.

FREUD, Sigmund. "Formulações sobre os dois princípio do funcionamento psíquico". Tradução Paulo César de Souza. São Paulo: Companhia das Letras, 2010c. FREUD, Sigmund. O eи e o Id. Tradução Paulo César de Souza. São Paulo: Companhia das Letras, 2011.

FREUD, Sigmund. Inibição, sintoma e angústia. Tradução Paulo César de Souza. São Paulo: Companhia das Letras, 2014.

KANT, I. Fundamentação da metafísica dos costumes. Tradução Paulo Quintel. Lisboa: 70,

2005.

KANT, I. Antropologia de um ponto de vista pragmático. Tradução Clélia Aparecida Martins. São Paulo: Iluminuras, 2006.

KANT, I. Crítica da faculdade do juízo. 2. ed. Tradução Valério Rohden e Antônio Marques, Rio de Janeiro: Forense, 2008.

KANT, I. Crítica da razão prática. Tradução Valério Rohden. São Paulo: Martins Fontes, 2016.

GOLDENBERG, Ricardo. Ensaio sobre a moral de Freud. Salvador: Agalma, 1994. ROGOZINSKI, Jacob. O dom da lei: Kant e o enigma da ética. Tradução Sílvio Rosa Filho. São Paulo: Discurso, Paulus, 2008.

Autor(a) para correspondência: Reginaldo Oliveira Silva, Universidade Estadual da Paraíba, R. Baraúnas, 351, Bairro Universitário, 58429-500, Campina Grande - PB, Brasil. rgnaldo@uol.com.br 